\title{
« Réflexions sur les empires parthe et sassanide. A propos de plusieurs livres récents ». Topoi, 9 , 1999 (2000), pp. 9-32.
}

\section{Rédaction}

\section{(2) OpenEdition}

10 Journals

\section{Édition électronique}

URL : http://journals.openedition.org/abstractairanica/35299

DOI : 10.4000/abstractairanica.35299

ISSN : 1961-960X

Éditeur :

CNRS (UMR 7528 Mondes iraniens et indiens), Éditions de l'IFRI

\section{Édition imprimée}

Date de publication : 15 mai 2002

ISSN : 0240-8910

\section{Référence électronique}

Rédaction, « "Réflexions sur les empires parthe et sassanide. A propos de plusieurs livres récents ». Topoi, 9, 1999 (2000), pp. 9-32. », Abstracta Iranica [En ligne], Volume 23 | 2002, document 90, mis en ligne le 08 février 2010, consulté le 25 septembre 2020. URL : http://journals.openedition.org/ abstractairanica/35299; DOI : https://doi.org/10.4000/abstractairanica.35299

Ce document a été généré automatiquement le 25 septembre 2020.

Tous droits réservés 
«Réflexions sur les empires parthe et sassanide. A propos de plusieurs livres récents ». Topoi, 9 , 1999 (2000), pp. 9-32.

\section{Rédaction}

L'A. voit quatre tendances majeures dans la recherche contemporaine sur ces périodes : intérêt pour les continuités, en dépit d'Alexandre le Grand et de changements dynastiques; plus grande prise en compte des régions orientales des empires parthe et sassanide, surtout grâce aux importantes découvertes en Asie centrale; nouvelle hiérarchie des sources écrites, au-delà des textes officiels, qui ne néglige plus les documents plus modestes (ostraka, parchemins, sceaux et monnaies).

\section{INDEX}

Thèmes : 3.2.3. Séleucides, Parthes et Sassanides

\section{AUTEURS}

RÉDACTION

Directeur de la revue et secrétariats (Paris et Téhéran) 